\title{
BIOLOGY
}

\section{Acoustic communication in two species of the Hypsiboas albopunctatus group (Anura: Hylidae) in sympatry and allopatry}

\author{
Raísa Romênia Silva Vieira ${ }^{*}$, Vinícius Guerra Batista² \& Rogério Pereira Bastos³
}

\begin{abstract}
'Programa de Pós-graduação em Ecologia e Evolução, Departamento de Ecologia, Universidade Federal de Goiás. Caixa Postal 131, 74001-970 Goiânia, GO, Brazil.

2Programa de Pós-graduação em Ecologia de Ambientes Aquáticos Continentais, Universidade Estadual de Maringá. Bloco G-90, Avenida Colombo 5790, 87020-900 Maringá, PR, Brazil.

${ }^{3}$ Laboratório de Herpetologia e Comportamento Animal, Departamento de Ecologia, ICB, Universidade Federal de Goiás. Caixa Postal 131, 74001-970 Goiânia, GO, Brazil.

‘Corresponding author. E-mail: raisa.rsv@gmail.com
\end{abstract}

\begin{abstract}
Tropical anuran communities are very diverse. Nevertheless, much of their ecological and historical processes remain unknown. Bioacoustical studies are important to help to solve these puzzles. In the present study we examined the effect of environmental (air temperature and humidity) and morphological (body size) attributes on the acoustic parameters of two frogs of the Hypsiboas albopunctatus species group ( $H$. albopunctatus and H. paranaiba) living in sympatry and allopatry in the Brazilian cerrado. We also investigated if the presence of one species influences the spatial distribution or vocal behaviour of the other. We found $H$. albopunctatus and $H$. paranaiba males emitting advertisement and aggressive calls in sympatry and allopatry. Although the calling behavior of $H$. paranaiba did not differ in sympatry and allopatry, differences were noted for $\mathrm{H}$. albopunctatus. Bioacoustics is the main form of communication in anurans, and is one of the best ways to discriminate among species. Variations in the calling behavior of males and what drives these variations in both species is central to better understand the processes of specific recognition and female attraction.
\end{abstract}

KEYWORDS. Acoustic interaction, acoustic partition, specific recognition, spatial partition.

Acoustic signals are the most evident features of the social behavior of anuran amphibians (WeLls 1977a, 2007). These signals carry information and have several roles in social organization, such as sexual selection (RoEsLi \& ReYNer 2000, BEE et al. 2010), maintenance of male spacing (BASTOS \& HADDAD 2002, Morais et al. 2012) and species identification (MARTins \& Jim 2003, Carvalho \& Giaretta 2013).

Among anurans breeding at the same site, heterospecific calls represent a noise that may interfere in the acoustical signal detection by males or females of the same species (RYAN \& Brenowitz 1985, Gerhardt \& Klump 1988, Narins \& Zelick 1988). To prevent such interference, males may choose vocalization sites that promote spatial segregation (РтACEK 1992, Martins et al. 2006), or adjust their vocal behavior (BRENOwITZ 1989, BASTOS et al. 2011). These strategies help to deflect niche space overlap, and consequently, competition (COLWELl \& RANGel 2009).

The advertisement call is the most commonly emitted acoustic signal among anurans, representing an important prezygotic isolation mechanism that prevents mismatings (HöDL
1977, Martins \& Jim 2003). Anurans can emit other types of vocalizations, each with a defined social function (HADDAD 1995, Guimarães et al. 2001, LemEs et al. 2012). The vocalizations may change due to abiotic (e.g. temperature, PrADo et al. 2005, LEMEs et al. 2012) and morphological factors (e.g. body mass, Bоsch \& DE LA Riva 2004, Morais et al. 2012), or in response to different social contexts (Bastos et al. 2011, Lemes et al. 2012, Gambale \& Bastos 2014). Those changes are strategic to maximize the reproductive success of males (Wells 1977b, BeE et al. 2001, Schwartz 2001).

The Hypsiboas albopunctatus species group comprises 10 species, nine of which are defined based on molecular characters (FArvovich et al. 2005), while one new species is based on adult morphology and advertisement call data (CARvalHo et al. 2010). Their distribution ranges throughout South and Central America (Frost 2014). We studied the acoustic repertoire of two species of this group, Hypsiboas albopunctatus (Spix, 1824) and Hypsiboas paranaiba (Carvalho, Giaretta \& Facure, 2010), which occur in allopatry and in sympatry. Our objectives were to determine: a) the role of the environment (air temperature and humidity) and 
morphology (body size) on call structure and b) if the presence of heterospecific individuals influence the spatial distribution, or vocal behavior, of the species involved.

\section{MATERIAL AND METHODS}

We performed the study in five water bodies inside the area of a mining company (Anglo American Brazil) and its surroundings, located in the municipality of Barro Alto $\left(15^{\circ} 04^{\prime} 52.34^{\prime \prime}\right.$, $48^{\circ} 56^{\prime} 51.49^{\prime \prime} \mathrm{W}$ ), state of Goiás, Brazil. The region is located in the domain of the Cerrado biome, a highly seasonal Neotropical savanna with two marked seasons: rainy (between October and March) and dry (between April and September). The water bodies sampled consisted of three 'veredas' (valley-side marshy grasslands, see Oliveira-Filho \& RATER 2002 for definition) where both species occur, a fourth 'vereda' occupied only by $H$. paranaiba, and a permanent pond occupied only by $H$. albopunctatus (Table 1 ).

Table 1. Geographical location and species of the Hypsiboas albopunctatus species group found in each site.

\begin{tabular}{lll}
\hline \multicolumn{1}{c}{ Site } & \multicolumn{1}{c}{ Geographical coordinates } & \multicolumn{1}{c}{ Species found } \\
\hline Vereda 1 & $15^{\circ} 05^{\prime} 47.8^{\prime \prime} \mathrm{S} ; 49^{\circ} 02^{\prime} 22^{\prime \prime} \mathrm{W}$ & H. albopunctatus and H. paranaiba \\
Vereda 2 & $15^{\circ} 04^{\prime} 51.7^{\prime \prime} \mathrm{S} ; 48^{\circ} 55^{\prime} 40.6^{\prime \prime} \mathrm{W}$ & H. albopunctatus and H. paranaiba \\
Vereda 3 & $15^{\circ} 05^{\prime} 02.51^{\prime \prime} \mathrm{S} ; 48^{\circ} 55^{\prime} 20.95^{\prime \prime} \mathrm{W}$ & H. albopunctatus and H. paranaiba \\
Vereda 4 & $15^{\circ} 05^{\prime} 00^{\prime \prime} \mathrm{S} ; 48^{\circ} 55^{\prime} 28^{\prime \prime} \mathrm{W}$ & H. paranaiba \\
Permanent pond & $15^{\circ} 05^{\prime} 09^{\prime \prime} \mathrm{S} ; 48^{\circ} 05^{\prime} 00^{\prime \prime} \mathrm{W}$ & H. albopunctatus \\
\hline
\end{tabular}

Recordings and observations were carried out between October 2009 and April 2010. Fieldwork was conducted from 1900 until 0000, which represents the peak of activity of the species in these sites. Calls were recorded with a MARANTZ PMD 660 digital recorder coupled with a Sennheiser ME66 microphone at about $50 \mathrm{~cm}$ from the calling frog. We measured the sound pressure level (SPL) of calls with a Minipa digital decibelimeter (Type II; fast setting; A weighting) at a $50 \mathrm{~cm}$ distance, oriented directly toward the calling male. The digital readout of the SPL meter was observed visually during the recording time. After each recording, we measured the snout-vent length (SVL) of males to the nearest $0.05 \mathrm{~mm}$ with a digital calliper and their mass to the nearest $0.01 \mathrm{~g}$ with digital scales. Air temperature and humidity were obtained with a digital thermo-hygrometer to the nearest $0.1^{\circ} \mathrm{C}$ and we measured the distance of calling males to the water and their perch height. We also registered the number of calling males of both species in the site by acoustic identification and visual encounters.

Vocalizations were recorded at sampling frequencies of 22 $\mathrm{kHz}$ and 16-bit resolution (wav files). We analyzed the temporal and spectral parameters of calls with Avisoft-Sonagraphy lite ${ }^{\circledR}$ and Cool Edit $96^{\circledR}$ software, respectively. Frequency information was obtained through Fast Fourier Transformation (FFT) of 1024 points width. For each individual, we analyzed five advertisement and five aggressive calls. The following acoustic parameters were measured: call duration (s), number of notes (notes/call), note duration (s), calling repetition rate (calls/min), and dominant, minimum and maximum frequencies $(\mathrm{Hz})$. Sound figures were obtained using Seewave package version 1.6.4 (Sueur et al. 2008) of the R platform (R Development Core Team 2012). Seewave settings were: window name (Fourier transform window) $=$ Hanning; window length $=256$ samples, overlap = $80 \%$. Bioacoustics terminology followed Gerhard \& Huber (2002) and WelLs (2007), based on spectral and temporal parameters. Voucher specimens are housed at the Zoological Collection of the Universidade Federal de Goiás (Hypsiboas paranaiba: ZUFG 5371, ZUFG 5372; Hypsiboas albopunctatus: ZUFG 5361).

We used multiple regression analysis to test if air temperature, air humidity, body size (value obtained by multiplying the SVL by the body mass) and number of calling males of both species influenced the acoustic parameters. To test if the species' calls differed between situations (calling alone or in the presence of the other species), we performed factorial analysis of variance (ANOVA) with residuals of multiple regressions to control for the effects of the variables mentioned above. A factorial ANOVA was also used to test if perch height and distance to water differed between situations. The tests followed ZAR (1999) and were performed in STATISTICA 7.0 with a significance level set at $\mathrm{p} \leq 0.05$. We used power tests to determine if our sampling protocol and analytical framework enable us to test our working hypothesis (FAUL et al. 2009).

\section{RESULTS}

Males of $H$. albopunctatus used several types of perch, such as dry branches, bushes, and leaves, and sometimes vocalized on the ground, wet or dry. Males kept a mean distance of $0.6 \pm 0.45$ $\mathrm{m}(0-2 \mathrm{~m}, \mathrm{n}=37)$ from the water and the mean perch height was $0.57 \pm 0.46 \mathrm{~m}(0-2 \mathrm{~m}, \mathrm{n}=37)$. The mean SVL and body mass of the individuals were, respectively, $48.35 \pm 3.14 \mathrm{~mm}$ (39.21-56.9 $\mathrm{mm}, \mathrm{n}=37)$ and $6.57 \pm 1.23 \mathrm{~g}(4-9.95 \mathrm{~g}, \mathrm{n}=37)$ and individuals did not differ in size across study sites.

We recorded the calls of 37 males of $H$. albopunctatus, 27 of which vocalized in the same site as $H$. paranaiba and 10 in allopatry. Males emitted advertisement and aggressive calls (Figs. 1-2). The former was the most frequent and exhibited different structures and functions (Table 2). Advertisement call duration was positively correlated and maximum frequency was negatively associated with air temperature, while call repetition rate and note duration had a positive correlation with body size and number of conspecific calling males, respectively (Table 3). Concerning the aggressive call, calling rate and SPL had a positive correlation and the maximum frequency had a negative correlation with body size, whereas the number of calling males was positively correlation with calling rate and call duration. We found no correlation between the other variables ( $p>0.05$ in all cases) (Table 3 ).

The calling sites used by $H$. paranaiba males were similar to those used by $H$. albopunctatus. The mean distance from the 


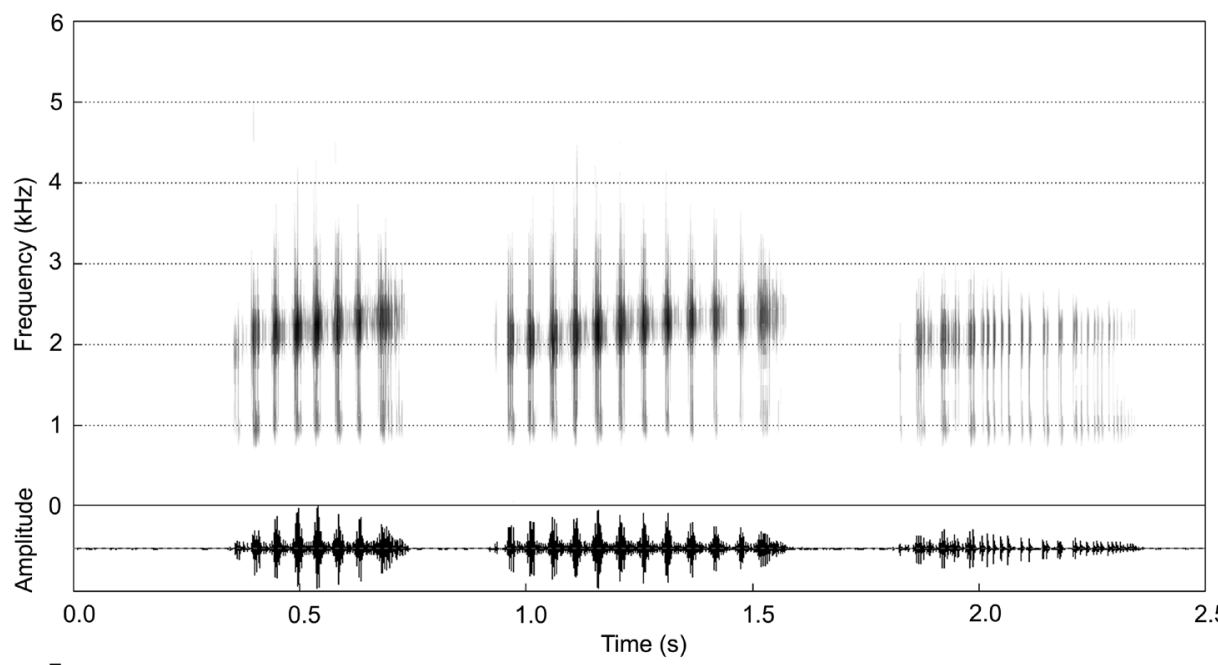

Amplitude

(dB)

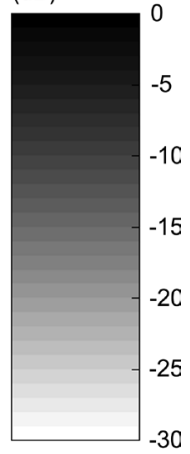

$-1 C$

$-15$

$-2 \mathrm{C}$

$-30$

1

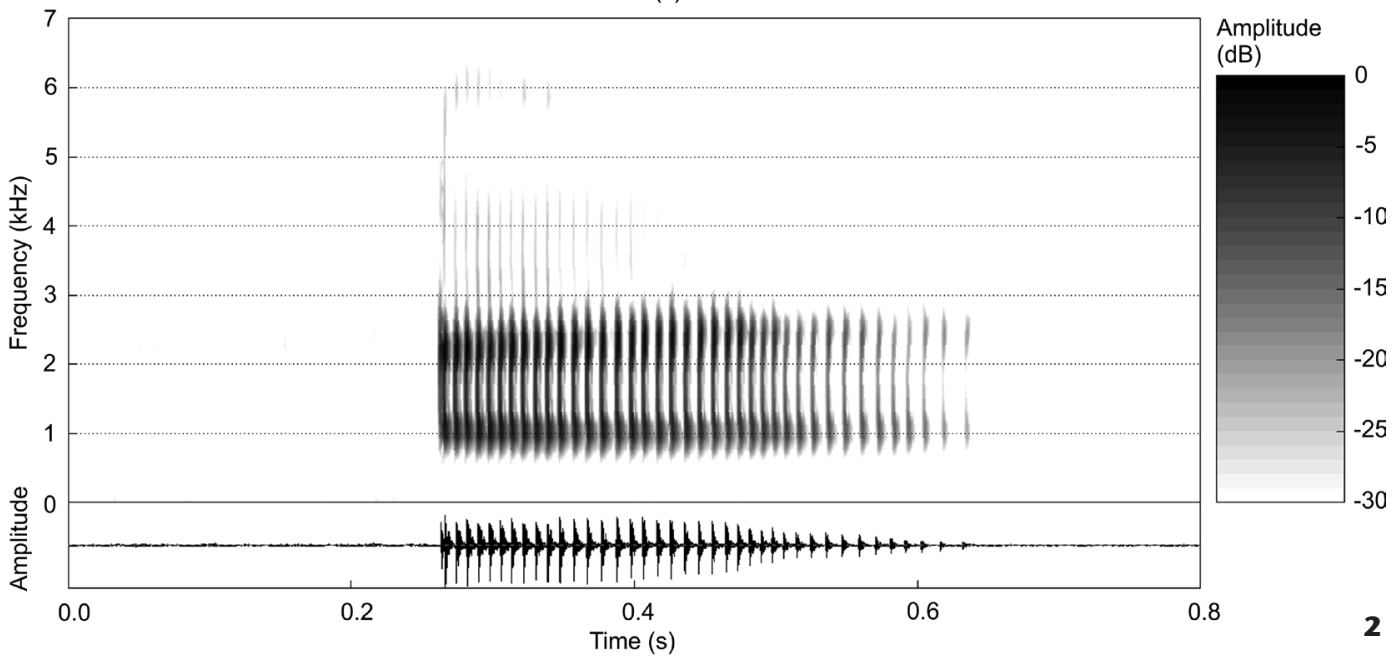

Figure 1-2. Advertisement (1) and aggressive (2) calls of Hypsiboas abopunctatus from Barro Alto, Goiás, Brazil. Above audiospectrogram, below oscillogram. (1) Air temperature $=23.4^{\circ} \mathrm{C}$, Air humidity $=68 \%$, SVL $=51,84 \mathrm{~mm}$; (2) Air temperature $=19,8^{\circ} \mathrm{C}$; Air humidity $=$ $88 \% ; S V L=50,27 \mathrm{~mm}$.

water was $0.46 \pm 0.33 \mathrm{~m}(0-1.25 \mathrm{~m}, \mathrm{n}=24)$, mean perch height was $0.47 \pm 0.36 \mathrm{~m}(0-1.4 \mathrm{~m}, \mathrm{n}=24)$. SVL and the body masses of the males were $46.17 \pm 2.06 \mathrm{~mm}(41.01-53.11 \mathrm{~mm}, \mathrm{n}=24)$ and $5.61 \pm 0.97 \mathrm{~g}(3.9-8.25 \mathrm{~g}, \mathrm{n}=24)$, respectively.

We recorded 24 males of $H$. paranaiba, 14 vocalizing in the same sites as $H$. albopunctatus and 10 in allopatry. Males emitted three types of vocalization: advertisement call and aggressive calls (named aggressive calls I and II) (Figs. 3-5). All three calls had different structures and aggressive call I was the most emitted (Table 2). Maximum frequency and calling rate of the advertisement call were positively associated with the number of calling males of the same species (Table 3). Regarding aggressive call I, the minimum frequency was negatively associated with body size and positively associated with air humidity, while SPL and calling rate were negatively associated with air temperature and positively associated with the number of conspecific calling males, respectively. No correlation was found between the other variables ( $p>0.05$ in all cases, Table 3 ). We did not include aggressive call II in the analysis because only a few individuals emitted this call.

Post-hoc power analysis revealed that statistical power to detect the relationships between acoustic parameters and morphological and environmental parameters were, in general, high for both species (Table 3 ).

There was no spatial segregation between $H$. albopunctatus and $H$. paranaiba, which means that in sympatry or allopatry individuals co-occur in the same reproductive sites. Perch height and distance from the water to calling male were the same for both species ( $\mathrm{p}>0.05$ for both cases). Hypsiboas albopunctatus males, regardless of calling with or without $H$. paranaiba, emitted 
Table 2. Acoustic parameters of advertisement and aggressive calls emitted by Hypsiboas albopunctatus and H. paranaiba individuals. The data represent the mean \pm standard deviation (sample size).

\begin{tabular}{|c|c|c|c|c|c|}
\hline \multirow{2}{*}{ Acoustic parameters } & \multicolumn{2}{|c|}{ Hypsiboas albopunctatus calls } & \multicolumn{3}{|c|}{ Hypsiboas paranaiba calls } \\
\hline & Advertisement & Agressive & Advertisement & Agressive I & Agressive II \\
\hline Repetition rate (calls/minute) & $6.68 \pm 5.61(37)$ & $3.03 \pm 2.27(37)$ & $1.88 \pm 1.80(24)$ & $5.67 \pm 3.58(24)$ & $1.72 \pm 1.68(10)$ \\
\hline Call duration (ms) & $34.79 \pm 104.65(185)$ & $0.37 \pm 0.09(171)$ & $1.66 \pm 0.68(98)$ & $0.92 \pm 0.12(112)$ & $0.45 \pm 0.20(36)$ \\
\hline Note number & $1.34 \pm 0.26(248)$ & $1 \pm 0(171)$ & $2.14 \pm 0.65(207)$ & $1 \pm 0(112)$ & $1 \pm 0(36)$ \\
\hline Note duration (ms) & $0.57 \pm 0.14(248)$ & $0.37 \pm 0.09(171)$ & $1.18 \pm 2.84(207)$ & $0.92 \pm 0.12(112)$ & $0.43 \pm 0.21(36)$ \\
\hline Dominant frequency $(\mathrm{Hz})$ & $2287.42 \pm 207.13(185)$ & $1149.96 \pm 222.63(171)$ & $2385.16 \pm 326.58(98)$ & $890.43 \pm 109.73(112)$ & $843.09 \pm 64.94(36)$ \\
\hline Maximum frequency $(\mathrm{Hz})$ & $5942.19 \pm 1019.73(185)$ & $3914.31 \pm 865.31(171)$ & $6587.47 \pm 872.86(98)$ & $3757.63 \pm 728.42(112)$ & $2897.45 \pm 806.21(36)$ \\
\hline Minimum frequency $(\mathrm{Hz})$ & $661.28 \pm 112.27(185)$ & $705.82 \pm 110.32(171)$ & $615.91 \pm 112.68(98)$ & $516.49 \pm 97.14(112)$ & $551.40 \pm 67.51(36)$ \\
\hline Sound Pressure Level (dB) & $74.47 \pm 6.96(185)$ & $62.96 \pm 6.68(171)$ & $75.99 \pm 4.90(98)$ & $64.73 \pm 6.53(112)$ & $66.05 \pm 5.94(36)$ \\
\hline
\end{tabular}

Table 3. Results of multiple regressions of morphological and environmental variables (MEV) with acoustic parameters of Hypsiboas paranaiba and $\mathrm{H}$. albopunctatus and values observed in power analysis.

\begin{tabular}{|c|c|c|c|c|c|}
\hline Species & Type of call & Acoustic parameters & MEV & Significance & Power analysis \\
\hline \multirow{15}{*}{ Hypsiboas albopunctatus } & \multirow{8}{*}{ Advertisement call } & Call duration (s) & Air temperature & $\beta=0.48 ; p<0.05$ & 0.801 \\
\hline & & Number of notes (notes/call) & No relation & $p>0.05$ & 0.628 \\
\hline & & Note duration (s) & Number of calling males & $\beta=0.51 ; p<0.01$ & 0.908 \\
\hline & & Repetition rate (calls/min) & Body size & $\beta=0.58 ; p<0.01$ & 0.896 \\
\hline & & Dominant frequency $(\mathrm{Hz})$ & No relation & $p>0.05$ & 0.935 \\
\hline & & Minimum frequency $(\mathrm{Hz})$ & No relation & $p>0.05$ & 0.684 \\
\hline & & Maximum frequency $(\mathrm{Hz})$ & Air temperature & $\beta=-0.48 ; p<0.05$ & 0.856 \\
\hline & & SPL & No relation & $p>0.05$ & 0.999 \\
\hline & \multirow{7}{*}{ Agressive call } & Call duration (s) & Number of calling males & $\beta=0.47 ; p<0.01$ & 0.999 \\
\hline & & \multirow{2}{*}{ Repetition rate (calls/min) } & Body size & $\beta=0.68 ; p<0.01$ & \multirow{2}{*}{0.980} \\
\hline & & & Number of calling males & $\beta=0.35 ; p<0.05$ & \\
\hline & & Dominant frequency $(\mathrm{Hz})$ & No relation & $p>0.05$ & 0.303 \\
\hline & & Minimum frequency $(\mathrm{Hz})$ & No relation & $p>0.05$ & 0.687 \\
\hline & & Maximum frequency $(\mathrm{Hz})$ & Body size & $\beta=-0.48 ; p<0.05$ & 0.645 \\
\hline & & SPL & Body size & $\beta=0.57 ; p<0.01$ & 0.999 \\
\hline \multirow{15}{*}{ Hypsiboas paranaiba } & \multirow{8}{*}{ Advertisement call } & Call duration (s) & No relation & $p>0.05$ & 1.000 \\
\hline & & Number of notes (notes/call) & No relation & $p>0.05$ & 1.000 \\
\hline & & Note duration (s) & No relation & $p>0.05$ & 0.266 \\
\hline & & Repetition rate (calls/min) & Number of calling males & $\beta=0.60 ; p<0.05$ & 0.703 \\
\hline & & Dominant frequency $(\mathrm{Hz})$ & No relation & $p>0.05$ & 0.933 \\
\hline & & Minimum frequency $(\mathrm{Hz})$ & No relation & $p>0.05$ & 0.962 \\
\hline & & Maximum frequency $(\mathrm{Hz})$ & Number of calling males & $\beta=0.59 ; p<0.05$ & 0.874 \\
\hline & & SPL & No relation & $p>0.05$ & 0.153 \\
\hline & \multirow{7}{*}{ Agressive call I } & Call duration (s) & No relation & $p>0.05$ & 0.999 \\
\hline & & Repetition rate (calls/min) & Number of calling males & $\beta=0.96 ; p<0.05$ & 0.988 \\
\hline & & Dominant frequency $(\mathrm{Hz})$ & No relation & $p>0.05$ & 0.982 \\
\hline & & Minimum fregur $\mathrm{H}(\mathrm{H}$ ) & Air humidity & $\beta=0.75 ; p<0.05$ & \multirow{2}{*}{1.000} \\
\hline & & Minımum frequency (Hz) & Body size & $\beta=-0.71 ; p<0.05$ & \\
\hline & & Maximum frequency $(\mathrm{Hz})$ & No relation & $p>0.05$ & 0.807 \\
\hline & & SPL & Air temperature & $\beta=-0.75 ; p<0.05$ & 0.979 \\
\hline
\end{tabular}



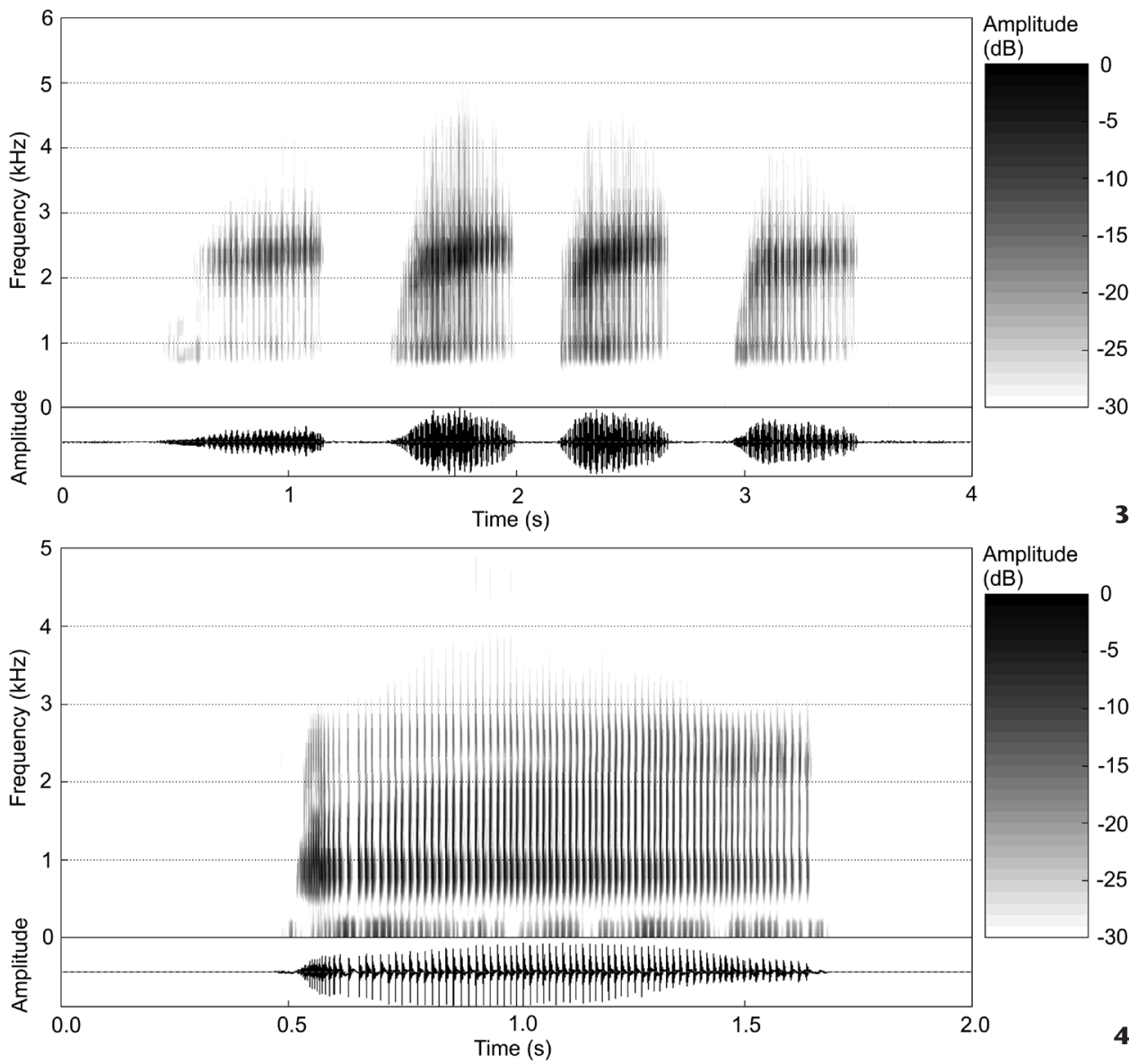

3

dB)
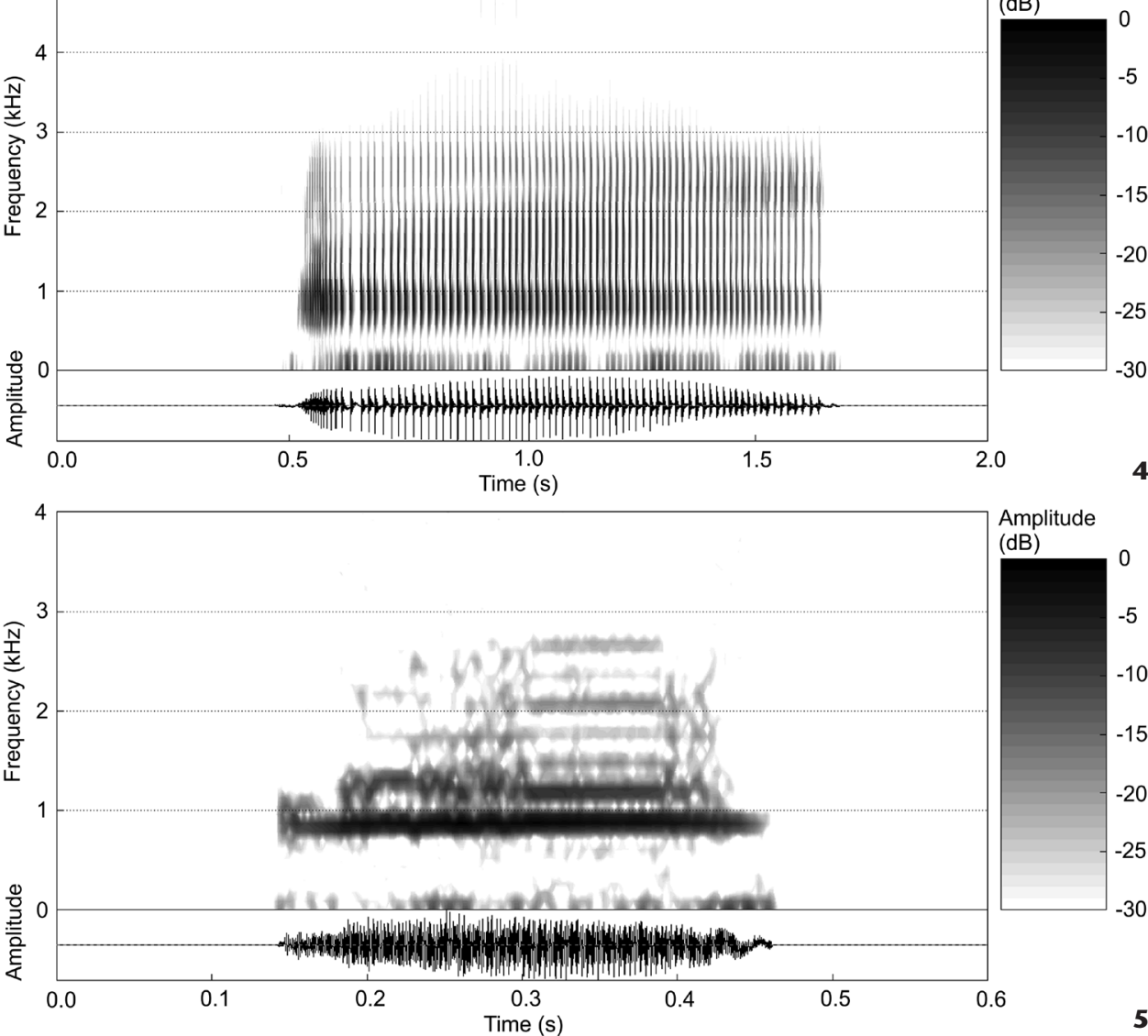

Amplitude

(dB)

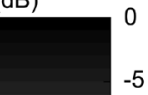

$-10$

$-15$

$-20$

$-25$

$-30$

Figure 3-5. Advertisement (3), aggressive I (4) and aggressive II (5) calls of Hypsiboas paranaiba from Barro Alto, Goiás, Brazil. Above audiospectrogram; below oscillogram. (3) Air temperature $=21^{\circ} \mathrm{C}$, Air humidity $=92 \%, \mathrm{SVL}=45.03 \mathrm{~mm}$; (4) Air temperature $=21^{\circ} \mathrm{C}$, Air humidity $=92 \%, \mathrm{SVL}=45.04 \mathrm{~mm}$; (5) Air temperature $=21^{\circ} \mathrm{C}$, Air humidity $=92 \%, \mathrm{SVL}=43.22 \mathrm{~mm}$.

advertisement calls with more notes $\left(\mathrm{F}_{(1.57)}=373.12, \mathrm{p}<0.01\right.$, Fig. 6) and notes with shorter duration $\left(\mathrm{F}_{(1.57)}=4.942, \mathrm{p}<0.05\right.$, Fig. 7) than $H$. paranaiba. However, when $H$. albopunctatus males called at the same sites as $H$. paranaiba males, their advertisement calls had lower SPL than the calls of conspecifics that called in allopatry $\left(\mathrm{F}_{(1.56)}=12.270, \mathrm{p}<0.01\right.$, Fig. 8). 

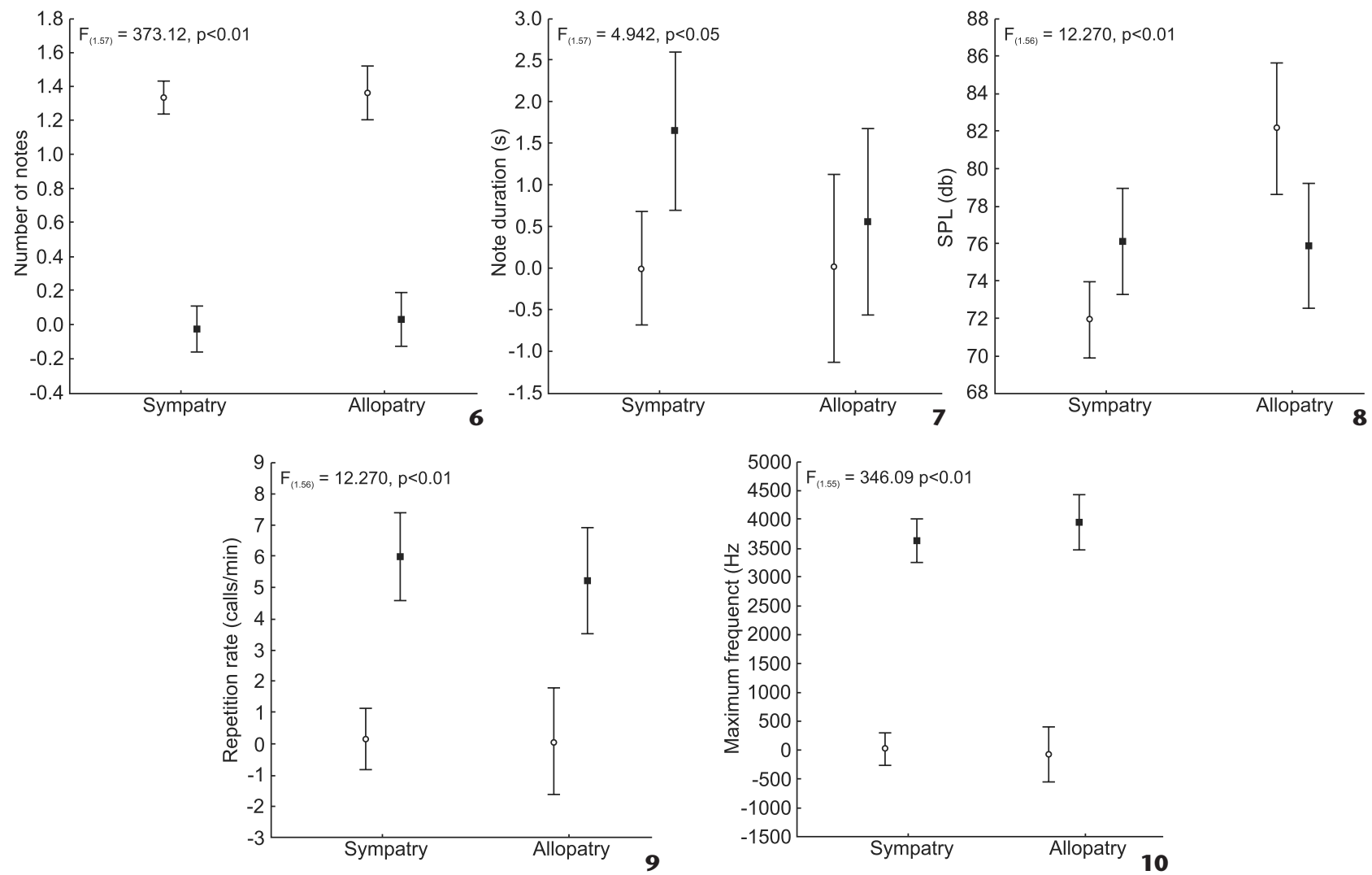

Figure 6-10. Mean and Standard Deviation of acoustic parameters of advertisement (6-8) and aggressive (9-10) calls of Hypsiboas albopunctatus $(\mathrm{O})$ and $H$. paranaiba $(\mathbf{\square})$ when in sympatry or allopatry.

Hypsiboas paranaiba males emitted aggressive calls I with a higher calling rate than $H$. albopunctatus males emitted aggressive calls $\left(\mathrm{F}_{(1.55)}=55.290, \mathrm{p}<0.01\right.$, Fig. 9). The maximum frequency of the aggressive calls of $H$. paranaiba' was higher than the aggressive calls of $H$. albopunctatus $\left(\mathrm{F}_{(1.55)}=346.09\right.$, $\mathrm{p}<0.01$, Fig. 10). We found no correlation between the other aggressive and advertisement call parameters of both species ( $p>0.05$ in all cases).

\section{DISCUSSION}

The vocal repertoire of both anuran species studied here is composed of advertisement and aggressive calls, as in other Neotropical species (HEyer et al. 1990, Guimarães \& BASTOS 2003, LEMEs et al. 2012). The advertisement calls of Hypsiboas albopunctatus analyzed are similar to those described by HEYER et al. (1990), De LA Riva et al. (1997) and Bastos et al. (2003). The aggressive calls are similar to those described by HeYER et al. (1990). The calls emitted by $H$. paranaiba are similar to those described by CARVALHO et al. (2010): advertisement calls are similar to note A, aggressive call I is similar to note B and aggressive call II is similar to note C (CARVALHo et al. 2010). We arrived at this conclusion based on the context of emissions and temporal structure of calls, as suggested by WeLLs (2007). This information is useful to demonstrate that we are dealing with the same species described formerly.

Power analysis can be used to point out whether an experiment had a good chance of detecting biologically significant differences in populations with statistically significant results. In the literature, 0.8 and 0.95 are conventionally considered "high power" values (CoHen 1988), but it is up to the researcher to make the judgment call concerning the cut values (Тномаs \& JuANE 1996). We believe that the values observed in the power analysis in this study are high enough to detect biologically significant effects, despite the fact that some few values are below 0.8 (Table 3 ).

The vocalizations studied here are formed by multipulsed notes with similar dominant frequencies and SPL; however, we found between species' call differences' that enable specific recognition. The advertisement calls of the two frogs differ in their temporal structures and their aggressive calls had different maximum frequencies. These differences presumably allow individuals to recognize conspecifics and inhabit the same habitats with other species (Bastos \& Haddad 1995, Martins \& JiM 2003). 
The most common vocalization of $H$. albopunctatus was the advertisement call, a pattern usually seen in other species (Lingnau et al. 2004, Lemes et al. 2012, Morais et al. 2012). However, $H$. paranaiba emitted more aggressive calls than advertisement calls. Although not typical, this behavior is also found in other anuran species - e.g., Phyllomedusa azurea Cope, 1862, (Guimarães et al. 2001). Aggressive calls are important in maintaining male spacing, territorial defense and warning opponents of the risk of physical combat, avoiding extra energy expenditure (SCHWARTz \& GERHARDT 1989, Rossa-Feres et al. 1999, GiASSON \& HADDAD 2006).

Our results demonstrated that some call parameters of both species were associated with environmental and morphological variables. The maximum frequency of the aggressive calls of $H$. albopunctatus and the minimum frequency of the aggressive calls of $H$. paranaiba were negatively correlated with body size. Usually, this relationship with morphology is found for the dominant frequency (e.g., Giasson \& Haddad 2006, Silva et al. 2008, Morais et al. 2012). In addition, these spectral parameters, similar to dominant frequency, are influenced by 'the size of the males' vocal cord and therefore are indicators of the males' body size (RYAN 1986). This signal may be used by other males to assess 'the fighting ability of an opponent and by females to evaluate which males are larger and better breeding partners (BEE et al. 2000). This highlights the importance of considering different call parameters in bioacoustical studies.

Body size positively influenced other call parameters of $H$. albopunctatus: the advertisement call rate, aggressive call SPL and calling rate. These parameters are associated with high energetic costs and could be indicators of the reproductive investment of males (Wells 1988, Bosch \& MÁrquez 1996). Larger males have greater strength and are able to invest more energy in breeding; they may also store larger amounts of air in their lungs and thus be capable of a higher repetition rate (Poole \& Murphy 2007).

Environmental factors (air temperature and humidity) are known to influence the temporal parameters of calls (GUIMARÃES \& Bastos 2003, Lignau \& Bastos 2007, Silva et al. 2008). As a consequence ectothermy,'the metabolic efficiency of amphibians improve with increasing temperature (Wells 2007), as seen for the duration of the advertisement call of $H$. albopunctatus. On the other hand, as found for' the SPL aggressive call of $H$. paranaiba, negative relationships between temperature and acoustic parameters can be observed (e.g. LINGNAU \& BASTOS 2007, Rodriguez et al. 2010, Morais et al. 2012). According to RoDriguEz et al. (2010), this relationship may represent a mechanism to avoid greater energy expenditure at higher temperatures.

Comparing the calling sites chosen by males of $\mathrm{H}$. albopunctatus and $H$. paranaiba, it is possible to conclude that there was a substantial overlap between them. The types of perch, perch height and distance from the calling male to the water were similar in both species. Species that vocalize at identical calling sites are rarely isolated by subtle differences in their preferences for calling position (HöDL 1977); therefore, we believe that the calling site is a weak mechanism of specific recognition and reproductive isolation in these species. This similarity may be the result of the close phylogenetic relationship between the species (Faivovich et al. 2005). According to Zimmerman \& SimberLoff (1996), congeners are likely to share ecological traits due to their evolutionary history.

The acoustic behavior of both species was influenced by the number of conspecifics calling at the site, as reported for other anurans (e.g., Lemes et al. 2012). Individuals appear to maintain a constant level of acoustic effort, but adjust their calls according to the social context (WeLLs 1988). They may also increase note duration, repetition rate and maximum frequency according to an increase in the SPL of other males. In general, changes in vocalizations work as a mechanism that indicates male competitiveness or attractiveness to females (Bosch \& Márquez 1996, Bastos et al. 2011).

When $H$. albopunctatus males vocalized in sympatry with $H$. paranaiba, they emitted calls with lower SPL than conspecifics that vocalized in allopatry. Differences in the intensities of the calls between sympatric and allopatric populations have been found for other Hylidae species (e.g., MárquEZ et al. 2005). Changes in the acoustic behavior of males are adaptations of species that vocalize in aggregates; males that avoid acoustic overlap are more likely to attract females (SULLIVAN \& LEEK 1987, Richardson et al. 2008). The intensity of the call regulates the spacing between males in the chorus and contributes to determining the aggressive threshold of males (BRENOWITZ 1989, LignAU \& BASTOS 2007). When males in a chorus change their acoustic behavior and avoid overlap, for instance by decreasing the amplitude of their calls, they also modify the acoustic threshold that elicits aggressive interactions and minimize costs from aggressive calls and physical combat (BRENOwitz \& Rose 1994, 1999).

Species coexistence can reflect niche partitioning in multiple levels (Albrecht \& Gotelli 2001), and here bioacoustics had the strongest evidence for niche overlap avoidance. Our results highlight the importance of acoustic behavior in discriminating anuran species, demonstrating that vocalizations, and not calling sites, are the main mechanism allowing reproductive isolation during the breeding season in sympatric Hylidae species.

\section{ACKNOWLEDGMENTS}

We thank Natan Maciel and Alessandro Morais for providing helpful comments on the manuscript. We are grateful to Instituto Chico Mendes de Conservação da Biodiversidade (ICMBio/RAN) for provided collecting permits. Financial support was provided by Anglo American Brazil, Fundação de Apoio à Pesquisa da Universidade Federal de Goiás (FUNAPE/ UFG), and Conselho Nacional de Desenvolvimento Científico e Tecnológico (CNPq process 476800/2011-0). For fellowships, R.P.Bastos acknowledge to CNPq, and R.R.S. Vieira and V.G. Batista to CAPES. 


\section{LITERATURE CITED}

Albrecht M, Gotelli NJ (2001) Spatial and temporal niche partitioning in grassland ants. Oecologia 126(1): 134-141. doi: $10.1007 / \mathrm{s} 004420000494$

Bastos RP, Haddad CFB (1995) Vocalizações e Interações Acústicas de Hyla elegans (Anura, Hylidae) durante a Atividade Reprodutiva. Naturalia 20: 165-176.

BASTOS RP, CFB HADDAD (2002) Acoustic and aggressive interactions in Scinax rizibilis (Anura: Hylidae) during the reproductive activity in southeastern Brazil. Amphibia-Reptilia 23(1): 97-104. doi: 10.1163/156853802320877654

Bastos RP, Motta JAO, Lima LP, Guimarães LD (2003) Anfíbios da Floresta Nacional de Silvânia, Estado de Goiás. Goiânia, Stylo Gráfica e Editora, 82p.

Bastos RP, Alcantara MB, Morais AR, Lingnau R, Signorelli L (2011) Vocal behavior and conspecific call response in Scinax centralis (Anura, Hylidae). Herpetological Journal 21(1): 43-50.

Bee MA, Perrill SA, Owen PC (2000) Male green frogs lower the pitch of acoustic signals in defense of territories: a possible dishonest signal of size? Behavioral Ecology 11(2): 169-177. doi: 10.1093/beheco/11.2.169

Bee MA, Kozich CE, Blackwell KJ, Gerhardt HC (2001) Individual Variation in Advertisement Calls of Territorial Male Green Frogs, Rana clamitans: Implications for Individual Discrimination. Ethology 107(1): 65-84.

Bee MA, Cook JM, Love EK, O’Bryan LR, Pettitt BA, Schrode K, Velez A (2010) Assessing acoustic signal variability and the potential for sexual selection and social recognition in Boreal chorus frogs (Pseudacris maculata). Ethology 116(6): 564-576. doi: 10.1111/j.1439-0310.2010.01773.x

Bosch J, Marquez R (1996) Discriminant functions for the sex identification in two midwife toads (Alytes obstetricans and $A$. cisternasii). Herpetological Journal 6: 105-109.

Bosch J, De La Riva I (2004) Are frog calls modulated by the environment? An analysis with anuran species from Bolivia. Canadian Journal of Zoology 82(6): 880-888. doi: 10.1139/ z04-060

Brenowitz EA (1989) Neighbor call amplitude influences aggressive behavior and intermale spacing in choruses of the pacific treefrog (Hyla regilla). Ethology 83(1): 69-79. doi: 10.1111/j.1439-0310.1989.tb00520.x

Brenowitz EA, Rose GJ (1994) Behavioural plasticity mediates aggression in choruses of the Pacific treefrog. Animal Behaviour 47(3): 633-641. doi: 10.1006/anbe.1994.1086

Brenowitz EA, Rose GJ (1999) Female choice and plasticity of male calling behaviour in the Pacific treefrog. Animal Behaviour 57(6): 1337-1342. doi: 10.1006/anbe.1999.1111

Carvalho TR, Giaretta AA, Facure KG (2010) A new species of Hypsiboas Wagler (Anura: Hylidae) closely related to $H$. paranaiba Günther from southeastern Brazil. Zootaxa 2521: 37-52.

Carvalho TR, Giaretta AA (2013) Bioacoustics reveals two new syntopic species of Adenomera steindachner (Anura: Lepto- dactylidae: Leptodactylinae) in the Cerrado of central Brazil. Zootaxa 3731(3): 533-551. doi: 10.11646/zootaxa.3731.4.6 CoHen J (1988) Statistical Power Analysis for the Behavioral Sciences. Hillsdale, Lawrence Erlbaum, $2^{\text {nd }}$ ed., 590p.

Colwell RK, Rangel TF (2009) Hutchinson's duality: the once and future niche. Proceedings of the National Academy of Sciences 106(Suppl. 2): 19651-19658. doi: 10.1073/ pnas.0901650106

De La Riva I, Márquez R, Bosch J (1997) Description of the advertisement calls of some South American Hylidae (Amphibia, Anura): taxonomic and methodological consequences. Bonner Zoologische Beiträge 47: 175-185.

Faivovich J, Haddad CFB, Garcia PCA, Frost DR, Campbell JA, Wheeler WC (2005) Systematic review of the frog family Hylidae, with special reference to Hylinae: a phylogenetic analysis and taxonomic revision. Bulletin of the American Museum of Natural History 294: 1-240. doi: 10.1206/0003-0090(2005)294[0001:SROTFF]2.0.CO;2

Faul F, Erdfelder E, Buchner A, Lang A-G (2009) Statistical power analyses using $\mathrm{G}^{\star}$ Power 3.1: Tests for correlation and regression analyses. Behavior Research Methods 41(4): 1149-1160. Frost DR (2014) Amphibian Species of the World: an Online Reference. New York, American Museum of Natural History, version 5.6. Electronic database available online at: http:// research.amnh.org/herpetology/amphibia/index.html [Accessed: 28/06/2014]

Gambale PG, Woitovicz-Cardoso M, Vieira RR, Batista VG, Ramos J, Bastos RP (2014) Composição e riqueza de anfíbios anuros em remanescentes de Cerrado do Brasil Central. Iheringia, Série Zoologia 104(1): 50-58. doi: 10.1590/1678-4766201410415058

Gerhardt HC, Klump GM (1988) Masking of acoustic signals by the chorus background noise in the green tree frog: a limitation on mate choice. Animal Behaviour 36(6): 1247-1249. doi: 10.1016/S0003-3472(88)80090-3

Gerhardt HC, Huber F (2002) Acoustic communication in insects and anurans: common problems and diverse solutions. Chicago, The University of Chicago Press, 542p.

Giasson LOM, Haddad CFB (2006) Social Interactions in Hypsiboas albomarginatus (Anura: Hylidae) and the Significance of Acoustic and Visual Signals. Journal of Herpetology 40(2): 171-180. doi: 10.1670/205-05A.1

Guimarães LD, Lima LP, Juliano RF, BASTos RP (2001) Vocalizações de espécies de anuros (Amphibia) no Brasil Central. Boletim do Museu Nacional 474: 1-14.

Guimarães LD, Bastos RP (2003) Vocalizações e Interações Acústicas em Hyla Raniceps (Anura, Hylidae) Durante a Atividade Reprodutiva. Iheringia, Série Zoologia 93(2): 149-158.

HADDAD CFB (1995) Comunicação em Anuros (Amphibia). Anais de Etologia 13: 3116-132.

Heyer WR, Rand AS, Cruz CAG, Peixoto OL, Nelson CE (1990) Frogs of Boracéia. Arquivos de Zoologia 31(4): 231-410.

HöbL W (1977) Call differences and calling sites segregation in 
anuran species from Central Amazonian floatins meadows. Oecologia 28(4): 351-363.

Lemes P, Tessarolo G, Morais AR, Bastos RP (2012) Acoustic Repertoire of Barycholos ternetzi (Anura: Strabomantidae) in Central Brazil. South American Journal of Herpetology 7(2): 455-464. doi: 10.2994/057.007.0205

Lingnau R, Guimarães LD, Bastos RP (2004) Vocalizações de Hyla werneri (Anura, Hylidae) no sul do Brasil. Phyllomedusa 3(2): 115-120.

LignaU R, BASTOS RP (2007) Vocalizations of the Brazilian torrent frog Hylodes heyeri (Anura: Hylodidae): repertoire and influence of air temperature on advertisement call variation. Journal of Natural History 41(17-20): 1227-1235. doi: 10.1080/00222930701395626

Márquez R, Moreira C, Amaral JPS, Pargana JM, Crespo EG (2005) Sound pressure level of advertisement calls of Hyla merdionalis and Hyla arborea. Amphibia-Reptilia 26(3): 391-395. doi: $10.1163 / 156853805774408603$

Martins IA, Jim J (2003) Bioacoustic Analysis of Advertisement Call in Hyla nana and Hyla sanborni (Anura, Hylidae) in Botucatu, São Paulo, Brazil. Brazilian Journal of Biology 63(3): 507-516. doi: 10.1590/S1519-69842003000300017

Martins IA, Almeida SC, Jim J (2006) Calling sites and acoustic partitioning in species of the Hyla nana and rubicundula groups (Anura, Hylidae). The Herpetological Journal 16(3): 239-247.

Morais AR, Batista VG, Gambale PG, Signorelli L, Bastos RP (2012) Acoustic communication in a Neotropical frog (Dendropsophus minutus): vocal repertoire, variability, and individual discrimination. Herpetological Journal 22(4): 249-257.

Narins PM, Zelick R (1988) The effects of noise on auditory processing and behavior in amphibians, p. 511-536. In: Fritzsch B, Ryan MJ, Wilczynski W (Eds.) The evolution of the amphibian auditory system. New York, John Wiley.

Oliveira-Filho AT, Ratter JA (2002) Vegetation physiognomies and woody flora of the cerrado biome, p. 91-120. In: OLIVEIRA PS, Marquis RJ (Eds.) The Cerrados of Brazil. Ecology and natural history of a neotropical savanna. NewYork, Columbia University Press.

Poole KG, Murphy CG (2007) Preferences of females barking treefrogs, Hyla gratiosa, for larger males: univariate and composite tests. Animal Behaviour 73(3): 513-524. doi: 10.1016/j.anbehav.2006.09.008

PTACEK MB (1992) Calling sites used by male gray treefrogs, Hyla versicolor and Hyla chrysoscelis, in sympatry and allopatry in Missouri. Herpetologica 48: 373-382.

Prado CPA, Uetanabaro M, Haddad CFB (2005) Breeding activity patterns, reproductive modes, and habitat use by anurans (Amphibia) in a seasonal environment in the Pantanal, Brazil. Amphibia-Reptilia 26(2): 211-221. doi: $10.1163 / 1568538054253375$

R Development Core Team (2012). R: A language and environment for statistical computing. Vienna, R Foundation for
Statistical Computing, ISBN: 3-900051-07-0, available online at: http://www.R-project.org

Richardson C, Léna JP, Joly P, Lengagne T (2008) Are leaders good mates? A study of call timing and male quality. Animal Behaviour 76(5): 1487-1495. doi: 10.1016/j.anbehav.2008.06.019

Ryan MJ, BRENOWITZ EA (1985) The role of body size, phylogeny, and ambient noise in the evolution of bird song. The American Naturalist 126: 87-100.

RYAN MJ (1986) Factors Influencing the Evolution of Acoustic Communication: Biological Constraints. Brain, Behavior and Evolution 28(1-3): 70-82. doi: 10.1159/000118693

Rodríguzz A, Nuez D, Alonso R (2010) Intraspecific variation in the advertisement call of the Cloud-Forest Frog Eleutherodactylus glamyrus (Anura: Eleutherodactylidae). Journal of Herpetology 44(3): 457-466. doi: 10.1670/09-038.1

RoesLi M, Reyner HU (2000) Male vocalization and female choice in the hybridogenetic Rana lessonae/Rana esculenta complex. Animal Behaviour 60(6): 745-755. doi: 10.1006/ anbe.2000.1519

Rossa-Feres DC, Menin M, Izzo TJ (1999) Ocorrência sazonal e comportamento territorial em Leptodactylus fuscus (Anura, Laptodactylidae). Iheringia, Série Zoologia 187: 93-100.

Schwartz JJ, Gerhardt HC (1989) Spatially mediated release from auditory masking in an anuran amphibian. Journal of Comparative Physiology 166(1): 37-41. doi: 10.1007/ BF00190207

SCHwartz JJ (2001) Call monitoring and interactive playback system in the study of acoustic interactions, p. 183-204. In: RYAN MJ (Ed.) Anuran communication. Washington, DC, Smithsonian Institution Press, 252p.

Silva CAD, Bastos RP, Telles MPC, Diniz Filho JAF (2008) Morphometric and genetic differentiation among populations of Eupemphix nattereri Steindachner, 1863 (Amphibia: Anura: Leptodactylidae) from Central Brazil. Iheringia, Série Zoologia 98: 493-500. doi: 10.1590/S0073-47212008000400013

Sueur J, Aubin T, Simonis C (2008). Seewave, a free modular tool for sound analysis and synthesis. Bioacoustics 18(2): 213226. doi: 10.1080/09524622.2008.9753600

SulLIVAN BK, LeEk MR (1987) Acoustic communication in Woodhouse's toad (Bufo woodhousei). Behaviour 103(1): 16-36. doi: 10.1163/156853987X00242

Thomas L, JuAnes F (1996) The importance of statistical power analysis: an example from Animal Behaviour. Animal Behaviour 52(4): 856-859.

Wells KD (1977a) The social behavior of anurans amphibians. Animal Behaviour 25: 666-693.

Wells KD (1977b) The Courtship of Frogs, p. 233-262. In: TAYLOR DH, GUTTMAN SI (Eds). The reproductive biology of amphibians. New York, Plenum Press.

WeLLS KD (1988) The effect of social interactions on anuran vocal behavior, p. 433-454. In: Fritzsch B, Ryan MJ, Wilczynski W, Hetherington TE, Walkowiak W (Eds). The evolution of the 
amphibian auditory system. New York, John Wiley and Sons.

WeLLS KD (2007) The Ecology and Behavior of Amphibians. Chicago, The University of Chicago Press, 1400p.

ZimMERMAN BL, SimberlofF D (1996) An historical interpretation of habitats use by frogs in a central Amazon forest. Journal of Biogeography 23(1): 27-46. doi: 10.1046/j.1365-2699.1996. d01-218.x

ZAR JH (1999) Biostatistical analysis. New Jersey, Prentice-Hall, $4^{\text {th }}$ ed.
Submitted: 6 April 2015

Received in revised form: 4 December 2015

Accepted: 7 February 2016

Editorial responsibility: Mauricio O. Moura

Author Contributions: RRSV and RPB designed the experiments; RRSV and VGB conducted the experiments and analyzed the data; RRSV, VGB and RPB wrote the paper.

Competing Interests: The authors have declared that no competing interests exist. 